\title{
Amine-Rich Coatings to Potentially Promote Cell Adhesion, Proliferation and Differentiation, and Reduce Microbial Colonization: Strategies for Generation and Characterization
}

\author{
Laurine Martocq ${ }^{1}$ (D) and Timothy E. L. Douglas 1,2,* \\ 1 Engineering Department, Lancaster University, Lancaster LA1 4YW, UK; 1.martocq@lancaster.ac.uk \\ 2 Materials Science Institute (MSI), Lancaster University, Lancaster LA1 4YW, UK \\ * Correspondence: t.douglas@lancaster.ac.uk
}

Citation: Martocq, L.; Douglas, T.E.L. Amine-Rich Coatings to Potentially Promote Cell Adhesion, Proliferation and Differentiation, and Reduce Microbial Colonization: Strategies for Generation and Characterization. Coatings 2021, 11, 983. https://doi.org/ 10.3390/coatings11080983

Academic Editor: Shigeng Song

Received: 23 July 2021

Accepted: 17 August 2021

Published: 18 August 2021

Publisher's Note: MDPI stays neutral with regard to jurisdictional claims in published maps and institutional affiliations.

Copyright: (c) 2021 by the authors. Licensee MDPI, Basel, Switzerland. This article is an open access article distributed under the terms and conditions of the Creative Commons Attribution (CC BY) license (https:/ / creativecommons.org/licenses/by/ $4.0 /)$.

\begin{abstract}
Biomaterial surface modification represents an important approach to obtain a better integration of the material in surrounding tissues. Different techniques are focused on improving cell support as well as avoiding efficiently the development of infections, such as by modifying the biomaterial surface with amine groups $\left(-\mathrm{NH}_{2}\right)$. Previous studies showed that $-\mathrm{NH}_{2}$ groups could promote cell adhesion and proliferation. Moreover, these chemical functionalities may be used to facilitate the attachment of molecules such as proteins or to endow antimicrobial properties. This mini-review gives an overview of different techniques which have been used to obtain aminerich coatings such as plasma methods and adsorption of biomolecules. In fact, different plasma treatment methods are commonly used with ammonia gas or by polymerization of precursors such as allylamine, as well as coatings of proteins (for example, collagen) or polymers containing $-\mathrm{NH}_{2}$ groups (for example, polyethyleneimine). Moreover, this mini-review will present the methods used to characterize such coatings and, in particular, quantify the $-\mathrm{NH}_{2}$ groups present on the surface by using dyes or chemical derivatization methods.
\end{abstract}

Keywords: amine groups; coatings; surface characterization; antimicrobial; cell behavior

\section{Introduction}

The use of implants or medical devices in the human body may cause problems of integration with surrounding tissues as well as infections due to microbial colonization. The World Health Organization estimates that out of 100 hospitalized patients, 7 in developed and 10 in developing countries will acquire at least one healthcare-associated infection (HCAI) [1]. HCAIs are infections acquired during hospitalization and represent one of the leading causes of death. The increase in HCAIs is mainly due to the problem of antimicrobial resistance. In fact, microorganisms develop several mutations that render antibiotics inefficient. It is estimated that by 2050, 10 million people will die every year because of this problem [2]. The most common resistant pathogens are some Gram-negative bacteria such as Klebsiella pneumonia and Escherichia coli, and Gram-positive bacteria such as Clostridium difficile and Staphylococcus aureus [3]. Most of these pathogens are resistant to antibiotics that make it difficult to reduce their number. In addition to the impact on the physical and mental health of the patient, these infections lead to a financial loss of about EUR 7 billion in Europe due to prolonged medical care of the patients and additional treatments. A study about the consequences of HCAIs in five European countries (France, Germany, UK, Spain, and Italy) showed the cost associated with these HCAIs and the increase in morbidity, mortality, and prolonged hospitalization [4].

To achieve a better biointegration of biomaterials into surrounding tissue, one strategy is the modification of the biomaterial surface. In fact, the biological response to biomaterials depends mainly on surface properties. By keeping the bulk properties of the materials, the surface properties may be modified to acquire or change different characteristics 
(wettability, topography, chemistry, ... ) in order to improve the biocompatibility of the material and avoid microbial colonization.

Amine $\left(-\mathrm{NH}_{2}\right)$ groups are known to promote cell adhesion because of their positive charges that can attract negatively charged biomolecules such as proteins or DNA in aqueous media at physiological pH [5]. Some studies showed that amine coatings could also promote cell attachment, proliferation, and osteogenic differentiation [6]. For implants, this advantage is important as it will determine if the implant succeeds due to the attachment and proliferation of cells. Another advantage of using these chemical groups is the possibility of exploiting them for the immobilization of molecules such as enzymes [7,8], antibiotics [9], or silver nanoparticles [10,11]. In this way, it is possible to endow antibacterial properties to the coating.

In this mini-review, the methods related to the generation of amine groups at the surface of the material will be discussed. A previous review focused on the production of amine-rich coatings by plasma for biomaterial applications and this has been already published [12]. However, to the best of our knowledge, no review including different methods of development of amine-rich coatings has been published for the biomaterials field. As shown in Figure 1, different general strategies have been identified:

- Application of plasma:

- Plasma surface activation with nitrogen $\left(\mathrm{N}_{2}\right)$ or ammonia $\left(\mathrm{NH}_{3}\right)$ gas;

- Plasma polymerization with a precursor containing $-\mathrm{NH}_{2}$ groups, such as allylamine.

- Chemical modification of the surface by adsorption of molecules:

- $\quad$ Proteins such as collagen or whey protein isolate (WPI);

- Synthetic polymers that contain $-\mathrm{NH}_{2}$ groups, such as polyethyleneimine (PEI) or polydopamine (PDA).

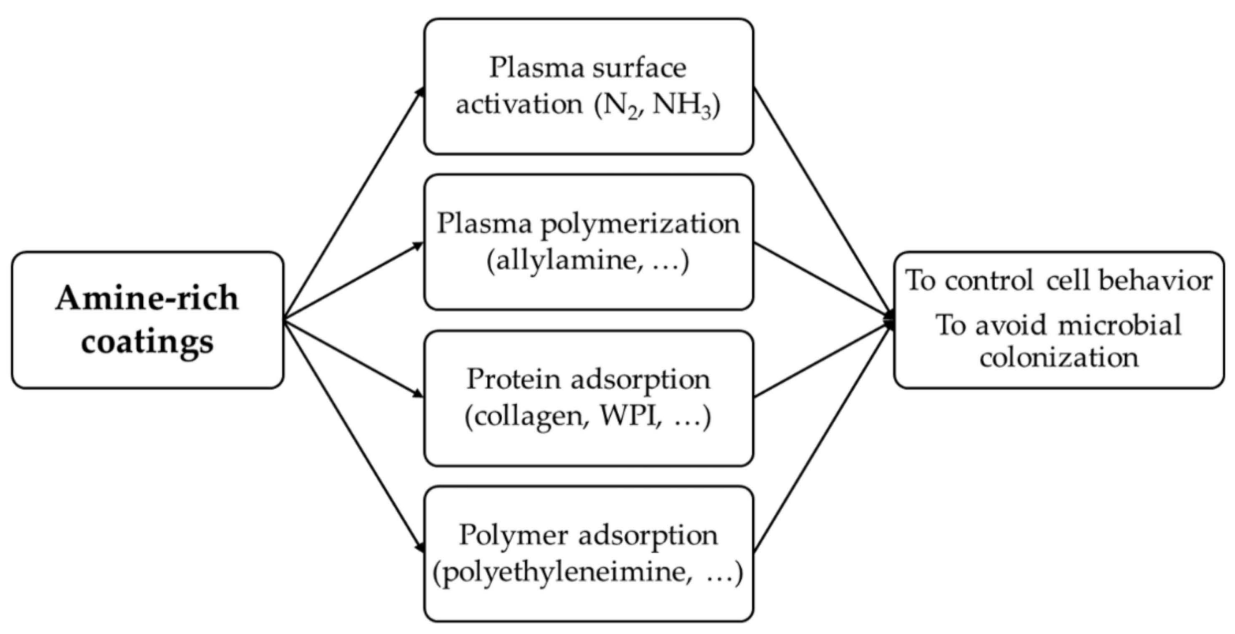

Figure 1. Methods used to obtain amine-rich coatings on biomaterials. WPI: whey protein isolate.

Finally, the techniques used to characterize the material and especially to quantify the amine groups will be presented:

- Physicochemical characterization of the coatings: contact angle (CA) measurements, X-ray photoelectron spectroscopy (XPS), scanning electron microscopy (SEM), atomic force microscopy (AFM), Fourier-transform infrared spectroscopy (FTIR);

- $\quad$ Amine groups quantification: dyes methods (Coomassie Brilliant Blue, Orange II) or chemical derivatization (with glutaraldehyde, or compounds in vapor phase). 


\section{Plasma Coatings}

\subsection{General Information on Plasma}

Plasma thin film deposition is of considerable importance for many industries in the world, such as the microelectronics and automobile industries. Moreover, it is of considerable interest for biomaterial applications. Plasma, also called the "fourth state of matter", is a macroscopically neutral and conductive ionized gas. It constitutes more than $99 \%$ of the visible matter of the universe (stars), but on Earth, it occurs only as a result of lightning or the northern or southern lights. However, there is a multitude of laboratory plasmas. Plasma is made up of a mixture of electrons, positive or negative ions, neutral molecules, and atoms that move freely in random directions. The electrons, being the lightest particles, have higher average energy than heavy particles such as ions, hence $T_{e} \gg T_{i}$. The two main properties of the plasma are electrical neutrality as well as the collective behavior of the particles (Figure 2). To create a plasma discharge, a voltage source is needed to conduct the current through a gas between two electrodes (Figure 2).

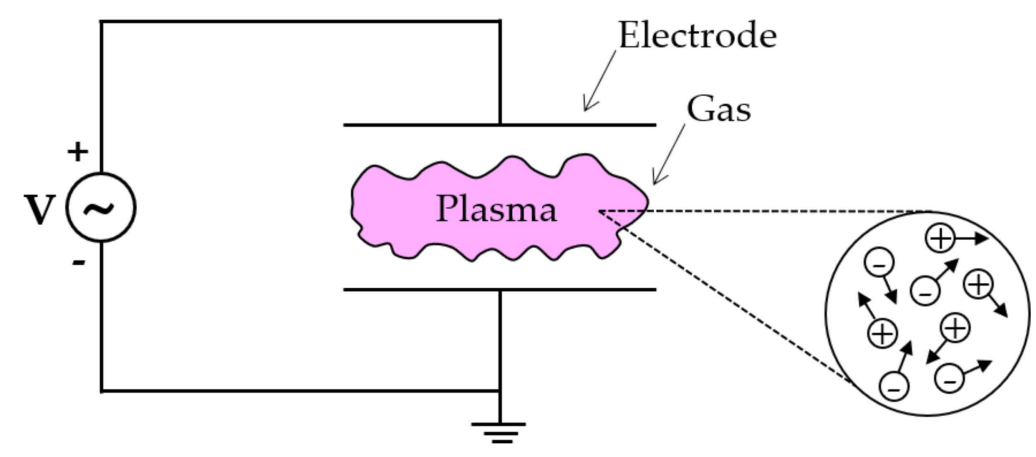

Figure 2. Schematic view of a plasma discharge between two electrodes connected to a voltage source. Plasma is a macroscopically neutral and conductive ionized gas constituted of a mixture of particles moving in all directions.

To obtain a plasma, several methods can be used with different types of power (continuous DC or alternative AC), at low/high or microwave frequency, different types of gas and pressures $[12,13]$. The initiation of a plasma discharge between two electrodes requires an electric field greater than the dielectric strength of the medium. Thus, a voltage higher than the breakdown voltage of the gas $V_{b}$ is applied, which depends on the pressure $p$ of the medium and the inter-electrode distance $d$ according to Paschen's law: $V_{b}=f(p \times d)$ [14]. Depending on the gas used and the parameters of the discharge, it is possible to deposit a variety of thin films at the surface of materials by tuning the pressure and the power. Plasma surface modification is generally a quick method to change homogeneously the surface properties in a one-step process [7]. A disadvantage of this process is the need of a vacuum chamber with a pumping system which may be expensive.

Different plasma techniques exist to prepare amine-rich coatings such as by plasma activation by the injection of inert gases such as ammonia $\left(\mathrm{NH}_{3}\right)$ or nitrogen $\left(\mathrm{N}_{2}\right)$, or by plasma polymerization of a monomer containing $-\mathrm{NH}_{2}$ groups such as allylamine. Plasma activation leads to the grafting of functional groups to the surface while plasma polymerization leads to the deposition of a thin polymeric film onto the surface.

\subsection{Plasma Amine-Rich Coatings}

Plasma technology has been widely used to produce amine-rich coatings by injecting precursors containing amine groups such as allylamine [6,15-18], heptylamine [19,20], ethylenediamine [21,22], or a mixture of compounds such as ammonia and ethylene [23-26]. These amine-rich coatings have been studied to control cell behavior demonstrating a positive effect on cell adhesion, proliferation, and differentiation for different cell types such as osteoblast-like cells [15,20,21] and fibroblasts [16]. Moreover, these coatings could 
be used to incorporate molecules such as enzymes, or drugs [9,27], as well as particles such as silver nanoparticles [10] to endow the material with new desirable biological properties. The application of such coatings on cell behavior, molecules' immobilization, and antimicrobial applications are elaborated in the following sections and summarized in Table 1.

Table 1. Overview of different applications of amine-rich coatings obtained by plasma and the findings associated.

\begin{tabular}{|c|c|c|c|c|}
\hline Application & Precursor & Substrate & Findings & Ref. \\
\hline \multirow{8}{*}{$\begin{array}{l}\text { Effect on cell } \\
\text { behavior }\end{array}$} & Mixture of $\mathrm{NH}_{3} / \mathrm{C}_{2} \mathrm{H}_{4}$ & $\begin{array}{l}\text { PTFE } \\
\text { PET }\end{array}$ & $\begin{array}{l}\text { Human umbilical vein endothelial cells' adhesion and } \\
\text { growth increased } \\
\text { More resistant to shear flow }\end{array}$ & [23] \\
\hline & Mixture of $\mathrm{N}_{2} / \mathrm{H}_{2}$ & Ti6Al4V & Human osteoblast cells' adhesion and spreading enhanced & [21] \\
\hline & Heptylamine & $\mathrm{Ti}$ & $\begin{array}{c}\text { Osteoblast-like cells' attachment increased after } 24 \mathrm{~h} \\
\text { Coating with high retention of }-\mathrm{NH}_{2} \text { groups enhanced actin } \\
\text { cytoskeleton formation }\end{array}$ & {$[20]$} \\
\hline & Ethylenediamine & Ti6Al4V & Human osteoblast cells' adhesion and spreading enhanced & $\begin{array}{l}{[21,} \\
22]\end{array}$ \\
\hline & \multirow{3}{*}{ Allylamine } & Ti6Al4V & Human osteoblast cells' adhesion and spreading enhanced & [21] \\
\hline & & Glass coverslips & $\begin{array}{l}\text { Human adipose-derived stem cells' attachment, spreading, } \\
\text { and proliferation enhanced } \\
\text { Osteogenic differentiation improved }\end{array}$ & {$[6]$} \\
\hline & & Silicone elastomer & Human skin fibroblasts' adhesion and spreading increased & [16] \\
\hline & Cyclopropylamine & $\begin{array}{l}\text { Tissue culture polystyrene } \\
\text { dishes } \\
\text { PCL nanofibers }\end{array}$ & $\begin{array}{l}\text { Initial adhesion of vascular smooth muscle cells (VSMCs) } \\
\text { improved for all plasma power settings tested } \\
\text { Proliferation and metabolic activity of VSMCs after } 7 \text { days } \\
\text { higher for coating made at } 33 \mathrm{~W} \\
\text { No increase in inflammatory markers }\end{array}$ & {$[28]$} \\
\hline \multirow{4}{*}{$\begin{array}{l}\text { Molecules' } \\
\text { immobilization }\end{array}$} & Mixture of $\mathrm{NH}_{3} / \mathrm{C}_{2} \mathrm{H}_{4}$ & PET & $\begin{array}{c}\text { Grafting of chondroitin sulfate and epidermal growth factor } \\
\text { to }-\mathrm{NH}_{2} \text { Decrease in cell apoptosis } \\
\text { VSMCs growth increased }\end{array}$ & [29] \\
\hline & Allylamine & $\mathrm{Si}$ & Grafting of trypsin & [30] \\
\hline & $\begin{array}{l}\mathrm{NH}_{3} n \text {-butyl amine } \\
\text { Allylamine }\end{array}$ & Polysulfone films & $\begin{array}{c}\text { Immobilization of glucose isomerase } \\
\text { Activity highest for allylamine/Ar plasma coatings close to } \\
\text { plasma edge }\end{array}$ & [31] \\
\hline & $\mathrm{NH}_{3}$ & Poly (D,L-lactide) & $\begin{array}{c}\text { Better anchoring of collagen on plasma-treated substrates } \\
\text { and resistance to PBS rinsing } \\
\text { Cell affinity of modified substrates improved }\end{array}$ & [32] \\
\hline \multirow{5}{*}{$\begin{array}{l}\text { Antimicrobial } \\
\text { applications }\end{array}$} & \multirow{3}{*}{ Allylamine } & $\begin{array}{l}\text { Silver nanoparticles } \\
\text { (AgNPs) coated with } \\
\text { polyvinyl sulphonate } \\
\text { (PVS) }\end{array}$ & $\begin{array}{l}\text { PVS coated-AgNPs were bound to allylamine coatings } \\
\text { Prevent attachment of S. epidermidis and biofilm formation }\end{array}$ & [11] \\
\hline & & $\begin{array}{l}\text { Anodic alumina oxide } \\
\qquad(\mathrm{AAO})\end{array}$ & $\begin{array}{c}\text { Substrate pores were loaded with vancomycin drug and } \\
\text { were reduced by plasma polymer deposition to allow a } \\
\text { controlled drug release }\end{array}$ & [33] \\
\hline & & Low-density polyethylene & $\begin{array}{l}\text { Bonding of antibacterial agents by immersion of the } \\
\text { coatings in antibacterial solutions }\end{array}$ & [9] \\
\hline & 1-vinylimidazole & $\begin{array}{l}\text { Thin-film composite } \\
\text { membranes }\end{array}$ & $\begin{array}{l}\text { Enhanced AgNPs binding onto the plasma-treated } \\
\text { substrates which cause a decrease in E.coli growth }\end{array}$ & [10] \\
\hline & Heptylamine & $\begin{array}{l}\text { Si/Glass/Thermanox } \\
\text { plastic/Cell culture plate }\end{array}$ & Release of antifungal drug & [27] \\
\hline
\end{tabular}

\subsubsection{Effect on Cell Behavior}

By using a gas containing amine groups, the material surface may be covered by an amine-rich coating. Different gases have been used to modify the material surfaces by adding chemical functionalities present in the plasma. Previous studies used a mixture of ammonia $\left(\mathrm{NH}_{3}\right)$ and ethylene $\left(\mathrm{C}_{2} \mathrm{H}_{4}\right)$ in a radiofrequency plasma reactor, to treat polytetrafluoroethylene (PTFE) and polyethylene terephthalate (PET) [23]. They demonstrated that human umbilical vein endothelial cells' adhesion was increased as well as their growth 
on these plasma-treated surfaces compared with uncoated surfaces (Figure 3). In addition, the cells were more resistant to induced shear flow [23].

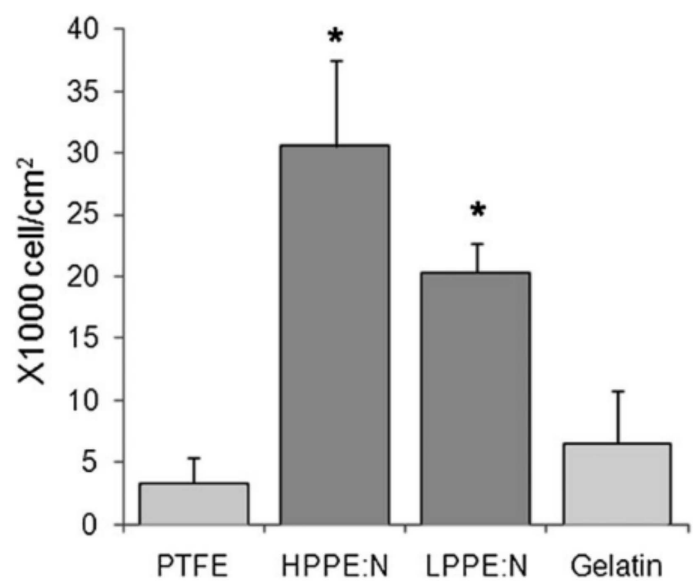

Figure 3. Human umbilical vein endothelial cell adhesion after $4 \mathrm{~h}$ on PTFE films, bare and coated with gelatin or with plasma polymerized coatings using low- (LPPE:N) and atmospheric-pressure (HPPE:N) plasma discharges. ${ }^{*} p<0.05$ compared to uncoated surfaces. Copyright (2011) Wiley. Used with permission from [23].

The other way to change surfaces of material by plasma technology is by polymerization of a monomer containing the chemical groups needed to functionalize the surface. Plasma polymerization allows the formation of thin polymeric coatings by using monomers. Different monomers have been used such as heptylamine $[19,20]$, or ethylenediamine [21,22]. Such coatings improved not only the initial adhesion [20] but also the spreading of osteoblasts on titanium (Ti) $[20,21]$. Ti surfaces obtained with the higher retention of $-\mathrm{NH}_{2}$ groups showed higher osteoblast-like cell attachment after $24 \mathrm{~h}$ of cell culture. SEM images confirmed this higher cell attachment. In fact, cells were flatter, with longer cellular extensions. This was further confirmed by actin labeling which showed that modified $\mathrm{Ti}$ with the high retention of $-\mathrm{NH}_{2}$ groups enhances actin cytoskeleton formation [20]. Similar results were obtained on Ti alloy, where cell adhesion and spreading were improved on coatings obtained with different precursors (allylamine, ethylenediamine, and a gas mixture of $\mathrm{N}_{2} / \mathrm{H}_{2}$ ) [21]. One of the main precursors rich in $-\mathrm{NH}_{2}$ groups used is allylamine. Liu et al. obtained an allylamine coating in a plasma RF reactor [6]. The allylamine coating obtained displayed hydrophilicity which can promote protein adsorption and cell adhesion. The authors showed that such coatings improve the attachment, spreading, and proliferation of human adipose-derived stem cells [6]. Moreover, their osteogenic differentiation was significantly improved compared with other coatings, without $-\mathrm{NH}_{2}$ groups, due to a higher mineralization level, as shown in Figure 4 [6]. This may be due to the changes in surface chemistry which affect protein conformation, such as fibronectin, and then the type of binding integrins. Integrins are important to mediate cell adhesion. The influence of $-\mathrm{NH}_{2}$ groups on cells may be also due to their positive charge in an aqueous medium at physiological $\mathrm{pH}$ (7.4), which attracts negatively charged biomolecules such as proteins or cells [5]. This can also explain the enhancement of osteogenic differentiation. Liu et al. described the possibility of a microenvironment with a higher $\mathrm{pH}$ value which can promote osteogenic differentiation. Moreover, another study of plasma functionalization with allylamine showed that these coatings enhanced the focal adhesion of osteoblastic cells [15]. A work from Ren et al., using allylamine to modify silicone elastomer by microwave plasma, showed that the biocompatibility of the material was improved. In fact, human skin fibroblasts adhered and spread well on the modified surface [16]. Recently, Nemcakova et al. studied the behavior of vascular smooth muscle cells (VSMCs) on amine-rich coatings with different plasma parameters and substrates [28]. The initial adhesion of VSMCs on all amine coated-polystyrene (PS) and polycaprolactone 
nanofibers (PCL NFs) was improved for the different plasma powers tested. However, the proliferation and metabolic activity of VSMCs, after 7 days in culture, were higher with the coating made at a power of $33 \mathrm{~W}$ due to better properties such as stability, $-\mathrm{NH}_{2}$ content, and wettability. The immunogenicity of such coatings was also investigated with the evaluation of inflammatory markers (TNF- $\alpha$ and IL-1 $\beta$ ) and showed no increase in their expression [28]. The mechanism of cell adhesion to nitrogen-rich coatings has been investigated by Girard-Lauriault et al. [34,35]. They demonstrated that a critical value of nitrogen concentration was necessary to induce cell adhesion for atmospheric-pressure plasma coating, which depends on the cell type [35]. Moreover, the role of amine groups to positively influence cell behavior has been confirmed [34]. Results showed the existence of a critical value of concentration of amine groups [34]. When the concentration of $-\mathrm{NH}_{2}$ groups was higher than the critical value, the adhesion of monocytes induced a transient expression of TNF- $\alpha$ and IL-1 $\beta$ which decrease within $24 \mathrm{~h}$ to control values. However, PPAR $\gamma$, a marker of monocytes adhesion and retention, had a more sustained expression for the same incubation period. The authors suggested that the transient expression of inflammatory markers (TNF- $\alpha$ and IL-1 $\beta$ ) may induce monocyte cell adhesion via the activation of PPAR $\gamma$ because previous studies showed that PPAR $\gamma$ can be induced by TNF- $\alpha$ and IL-1 $\beta$ [34].
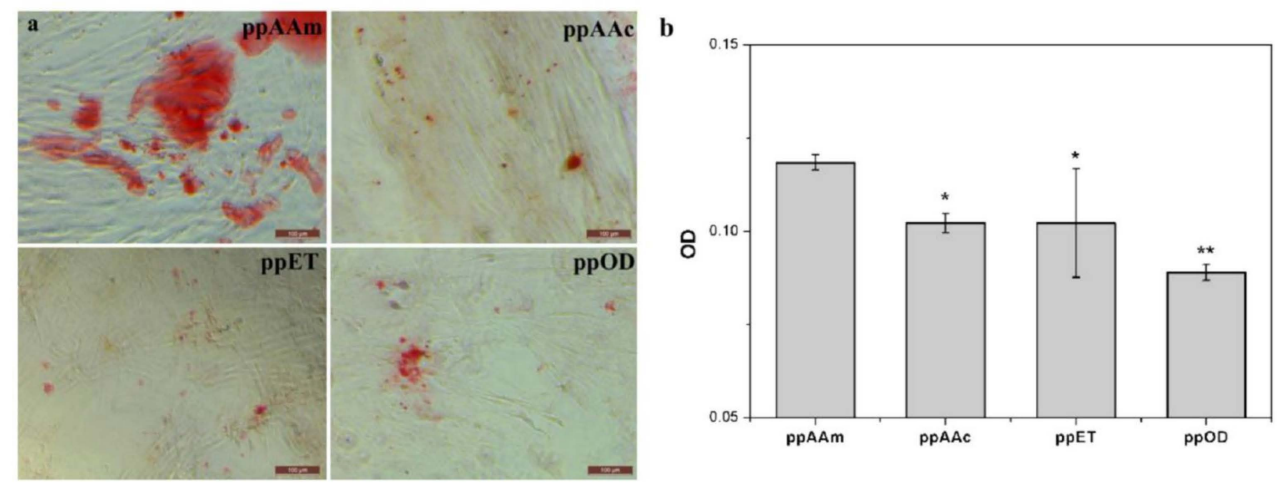

Figure 4. (a) Alizarin Red S staining for mineral deposition formed by hASCs cultured on different samples in medium with osteogenic supplement at day 14. (b) The quantitative result of retention of Alizarin Red. Data were expressed as means $\pm \mathrm{SD}$ ( $n=4$ for each sample). Single asterisk * and double asterisks ${ }^{* *}$ denote a statistical significance of $p<0.05$ and $p<0.01$, respectively, compared with data obtained on the ppAAm sample. Reprinted with permission from [6]. Copyright (2014) American Chemical Society.

Finally, cell behavior can be also controlled by grafting molecules to amine groups. A previous study investigated the use of these functionalities to graft chondroitin sulfate (CS) and epidermal growth factor (EGF) to promote healing around stents [29]. The $-\mathrm{NH}_{2}$ coatings were obtained by plasma with a mixture of $\mathrm{NH}_{3}$ and $\mathrm{C}_{2} \mathrm{H}_{4}$. Cell experiment results showed a decrease in cell apoptosis after 6 and $24 \mathrm{~h}$ on plasma coated with CS + EGF-grafted PET compared with untreated PET. Moreover, the coatings significantly increased vascular smooth muscle cells (VSMC) growth [29]. The use of $-\mathrm{NH}_{2}$ groups to immobilize molecules will be further discussed in the next part.

\subsubsection{Molecules' Immobilization}

As mentioned in the previous part, amine-rich coatings can also be used to immobilize molecules such as bioactive molecules such as CS and EGF [29]. These coatings can also be used to immobilize other molecules such as enzymes or drugs. A previous study prepared amine-rich coatings by allylamine plasma and covalently attached an enzyme, trypsin, via $-\mathrm{NH}_{2}$ groups [30]. Similar work was performed with ammonia; $n$-butylamine and allylamine plasma and glucose isomerase were successfully immobilized on the modified samples [31]. Ammonia plasma has been also used to modify poly (D, L-lactide) and coat collagen on it to improve cell affinity and the resistance of the coatings [32]. Collagen coated 
on plasma-treated samples seems to be more resistant to PBS rinsing due to interactions between collagen and plasma-treated surfaces. Finally, different molecules, such as silver nanoparticles [10] or drugs $[9,27,33]$, have been incorporated in these coatings to make them antibacterial, which will be discussed in the following part.

\subsubsection{Antimicrobial Applications}

Microorganisms' growth has also been inhibited by using amine coatings on the surface of the material. In fact, some studies used amine groups to functionalize material surfaces with silver nanoparticles (AgNPs) due to a strong affinity $[10,11]$. These AgNPs, which are known for their antimicrobial properties, were found to be responsible for the decrease in E. coli growth [10]. Allylamine thin films deposited by plasma have also been used to control the release of drugs such as vancomycin from porous material by reducing the pore diameters at the surface of the material [33]. A previous study demonstrated the ability of allylamine coatings to graft antibacterial agents onto low-density polyethylene (LDPE) samples [9]. The surfaces were first pretreated by air plasma, then treated by allylamine coatings. Finally, these coatings were immersed into antibacterial solutions (benzalkonium chloride, bronopol, chlorhexidine, and triclosan) for $24 \mathrm{~h}$, leading to the bonding of the antibacterial agents to the surface, which was confirmed by XPS and FTIR. The antibacterial tests demonstrated higher antibacterial activity for samples treated with allylamine due to a higher quantity of antibacterial agent grafted. A following work by the same authors showed the effect of the monomer used on antibacterial agent grafting [36]. Three monomers (allylamine, N-allylmethylamine, and N,N-dimethylallylamine) were tested and they demonstrated that less antibacterial agent was grafted onto the allylamine coating compared with the two others. Recently, heptylamine coating has been used as a matrix for the release of fluconazole, an antifungal drug. Results showed a significant reduction in C. albicans colonies after $48 \mathrm{~h}$ due to a controlled release of the drug [27].

\section{Protein Coatings}

Proteins are widely available and certain proteins such as fibronectin or collagen are present in the human body. Collagen and fibronectin are well known to have binding sites for cells and have been extremely widely employed as biomaterial [37,38]. However, they are expensive proteins, and therefore, whey protein could constitute an alternative due to its low cost: WPI preparations, such as BiPro from Davisco Inc. and used in previous studies [39], typically cost tens of US dollars per $\mathrm{kg}$, while collagen preparations used to coat biomaterial surfaces, such as those from Sigma Aldrich and BD Biosciences $[40,41]$, would typically cost hundreds of US dollars per g. Due to a high surface/volume ratio, fibrillar structures are interesting candidates to coat materials since this increases the adherence at the surface. Moreover, compared with globular proteins which may change their conformation after adsorption on the material's surface, fibrillar proteins are unlikely to $[42,43]$. Fibrillar proteins are generally larger than globular proteins which means that they are likely to have more adhesion points to substrates. In addition to their high stability, properties can be added to the coating such as antibacterial properties, by binding other molecules to the fibrillar structures [44,45]. Fibrillar structures could even form aligned superstructure scaffolds for cells [46]. Functional lysozyme fibrils coatings improved attachment of immortalized fibroblasts and epithelial cell lines and can act as biomimetic cell culture platforms [47-49]. Fibrils are obtained from fibrous proteins such as collagen or whey protein isolate (WPI).

The application of protein coatings such as FN, collagen, and amyloid fibrillar coatings are discussed in the following sections and summarized in Table 2. 
Table 2. Overview of different applications of amine-rich coatings obtained with proteins and the findings associated.

\begin{tabular}{|c|c|c|c|}
\hline Protein & Substrate & Findings & Ref. \\
\hline \multirow{3}{*}{ Fibronectin (FN) } & $\begin{array}{l}\text { Poly (lactic acid) (PLLA) } \\
\text { Silicon oxide (SO) }\end{array}$ & $\begin{array}{l}\text { Osteoblast-like cells' adhesion and spreading enhanced after } 3 \text { days } \\
\text { Cell proliferation and mitochondrial activity improved after } 7 \text { days }\end{array}$ & [50] \\
\hline & $\mathrm{Si}$ & $\begin{array}{l}\text { Human osteoprogenitor cells' attachment enhanced and formation of actin filaments } \\
\text { Formation of dense stress fibers attached to FN coatings }\end{array}$ & {$[51]$} \\
\hline & PTFE & $\begin{array}{c}\text { FN combined with phosphorylcholine } \\
\text { Endothelial cells' adhesion and spreading enhanced } \\
\text { Higher cell viability after } 24 \mathrm{~h}\end{array}$ & [52] \\
\hline \multirow{5}{*}{ Collagen } & & Osteoblast cells' initial adhesion enhanced & [53] \\
\hline & & Osteoblast cells' spreading, proliferation and differentiation improved & [54] \\
\hline & Ti6Al4V & $\begin{array}{c}\text { Collagen coupled with phloroglucinol (PG) } \\
\text { Fibroblast- and osteoblast-like cells adhere and spread well } \\
\text { Reduction in inflammatory response } \\
\text { Osteogenic differentiation promoted with a high PG concentration } \\
\text { Osteoclast activation reduced with a low PG concentration }\end{array}$ & [55] \\
\hline & $\mathrm{Ti}$ & Early osseointegration enhanced in vivo & [56] \\
\hline & Porous Ti oxide & $\begin{array}{l}\text { Collagen coating coupled with AgNPs } \\
\text { Osteoblast cells' adhesion improved } \\
\text { Adhesion and proliferation of E.coli were reduced }\end{array}$ & [57] \\
\hline \multirow{5}{*}{$\begin{array}{l}\text { Amyloid fibrils from } \\
\text { whey protein isolate } \\
\text { (WPI) }\end{array}$} & Hydrogel (no substrate) & $\begin{array}{c}\text { Osteoblast and fibroblast cells' growth enhanced } \\
\text { Calcium deposition of osteoblasts increased } \\
\text { Osteogenic differentiation of human adipose-derived stem cells increased }\end{array}$ & [58] \\
\hline & & $\begin{array}{l}\text { WPI coupled with aragonite } \\
\text { Osteoblast cells' proliferation supported for } 3 \text { weeks }\end{array}$ & [59] \\
\hline & $\begin{array}{l}\text { Turkey Frankfurter (food } \\
\text { application) }\end{array}$ & $\begin{array}{l}\text { Nisin, grape seed extract, malic aid, and ethylenediamine tetraacetic acid } \\
\text { incorporated in WPI coatings } \\
\text { Effective antimicrobial activity against different pathogens }\end{array}$ & [60] \\
\hline & Films (no substrate) & $\begin{array}{l}\text { Oregano, rosemary, and garlic essential oils incorporated in WPI films } \\
\text { Film containing oregano and garlic essential oil most effective against S. aureus, S. } \\
\text { enteritidis, L. monocytogenes, E. coli, and L. plantarum }\end{array}$ & [61] \\
\hline & Glass & $\begin{array}{l}\text { Resistance of WPI fibrillar coatings to autoclave sterilization } \\
\text { Human bone marrow stromal cells' spreading, and differentiation enhanced }\end{array}$ & [39] \\
\hline $\begin{array}{l}\text { Amyloid fibrils from } \\
\text { lysozyme }\end{array}$ & Mica & $\begin{array}{l}\text { Fibroblast and epithelial cells' spreading increased } \\
\text { Increased of focal adhesion and associated stress fibers }\end{array}$ & [48] \\
\hline \multirow{3}{*}{ Silk fibroin (SF) } & $\mathrm{Ti}$ & $\begin{array}{l}\text { Gentamycin and silver nanoparticles incorporated to SF coatings } \\
\text { Antibacterial activity against S.aureus } \\
\text { Osteoblast cells' adhesion, growth, and osteogenic activities enhanced }\end{array}$ & [62] \\
\hline & PEEK & $\begin{array}{c}\text { SF combined with bone-forming peptide } \\
\text { Initial attachment and proliferation supported } \\
\text { Osteoblast cell proliferation, spreading, and osteogenic differentiation enhanced } \\
\text { for SF with bone-forming peptide coating }\end{array}$ & [63] \\
\hline & Electrospun nanofibers & $\begin{array}{l}\text { SF modified with graphene oxide which resulted in a } \\
\text { Decrease in E. coli and S. aureus survival rates } \\
\text { Osteoblast cells' growth enhanced }\end{array}$ & [64] \\
\hline- & Electrospun nanofibers & $\begin{array}{l}\text { SF combined with heparin } \\
\text { Cell growth and proliferation improved }\end{array}$ & [65] \\
\hline
\end{tabular}

\subsection{Globular Protein Coatings}

Fibronectin (FN) is a well-known globular protein present in two different forms in the human body: an insoluble form in the extracellular matrix and a soluble form in the body fluids such as plasma. This protein can interact with different macromolecules such as collagen or heparin, and promote cell attachment [38,66-68]. It is also involved in cell migration during embryonic development as well as in wound healing [69]. FN has been widely studied, especially with a view to modifying biomaterials' surfaces to improve their biocompatibility [70]. Depending on its conformation, FN interacts with cells via integrins and promotes cell attachment and proliferation [71]. A study investigated FN adsorption on poly (lactic acid) (PLLA) and silicon oxide (SO) substrates [50]. It was found 
that osteoblast-like cell adhesion was enhanced by the presence of FN on both surfaces as well as cell spreading after $3 \mathrm{~h}$ culture. Moreover, cell proliferation and mitochondrial activity after 7 days of culture were improved in the presence of FN [50]. The effect of FN adsorption on cell attachment has also been investigated on other substrates such as silicon [51]. The attachment of human osteoprogenitor cells with the formation of actin filaments was enhanced due to the presence of FN. Moreover, the formation of dense stress fibers attached to the FN coatings was noticed, as indicated in Figure 5. A FN coating has also been combined with other biomolecules such as phosphorylcholine, to enhance endothelialization as well as to avoid thrombus formation [52]. The authors found that the adhesion of endothelial cells on FN coatings was enhanced compared with uncoated polytetrafluoroethylene (PTFE). Moreover, cell spreading was improved on FN coatings. Finally, the study of the cell metabolic activity after $24 \mathrm{~h}$ showed higher cell viability on FN coatings compared with uncoated PTFE.

A
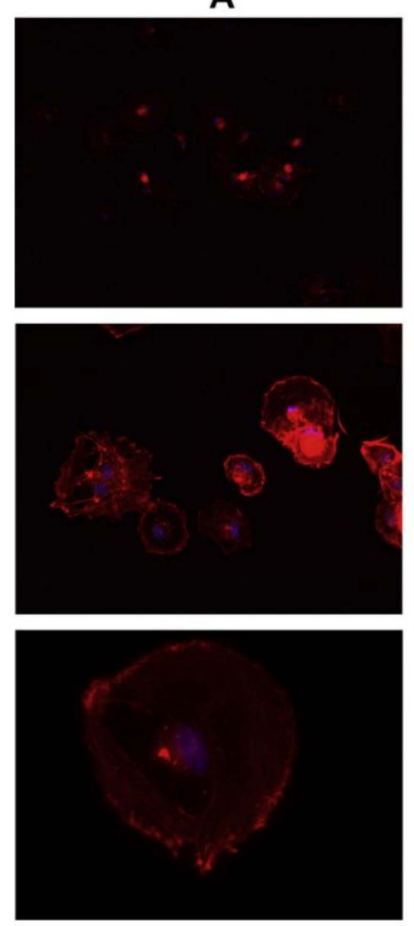

B
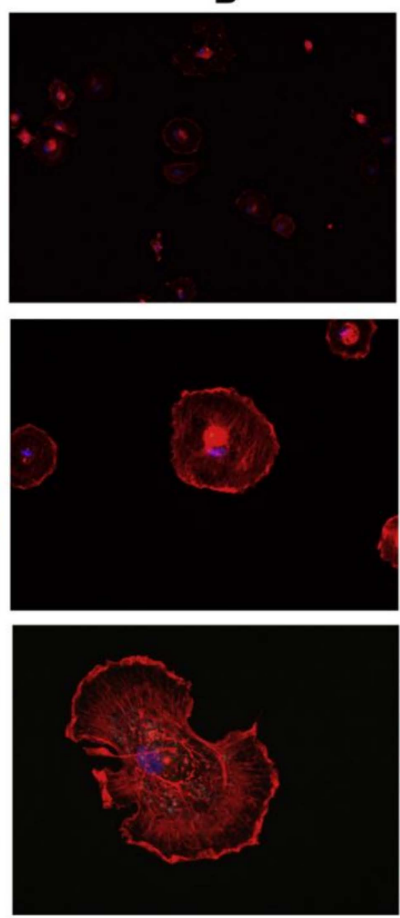

C
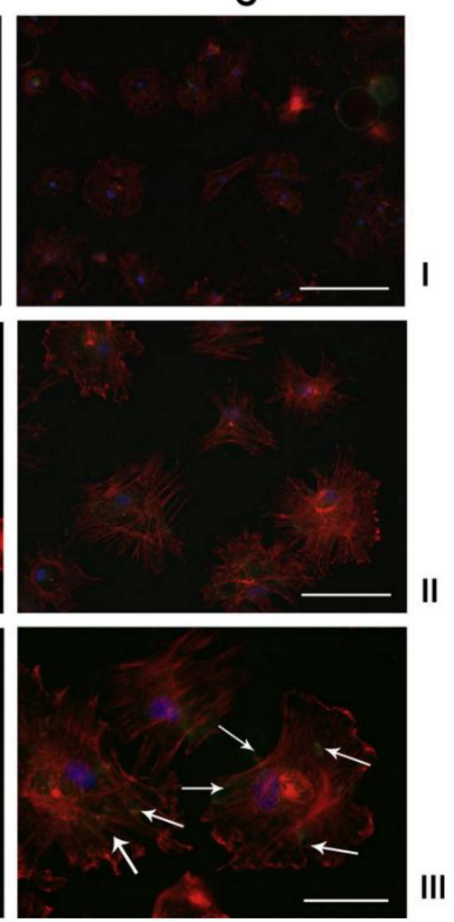

Figure 5. Human osteoprogenitor cell actin filament staining on (A) standard cover slips, (B) silicon and (C) FN-covered silicon after $3 \mathrm{~h}$ in cell culture. Red color stains actin and blue stains cell nuclei. On Figure 5c, white arrows indicate the green staining of the dense stress fibers attached to the FN coating. Scale bars are of 200 (I), 100 (II) and 50 (III) $\mu \mathrm{m}$, respectively. Reprinted with permission from [51]. Copyright (2011), with permission from Elsevier.

\subsection{Fibrillar Coatings \\ 3.2.1. Collagen Fibrillar Coatings}

Many studies focus on the use of collagen coatings for biomedical applications. In fact, collagens represent a major part of the extracellular matrix [72]. They contribute to the mechanical properties and biological functions of various types of tissues, such as skin, bone, or blood vessels. Collagen is found in multicellular animals and represents about $25 \%$ of all body proteins, making it the most abundant protein [73]. There are approximately 28 collagen types, but types I, II, and III are the most predominant. Collagens provide structural support to tissue, and they mediate adhesion, migration, and proliferation of cells. Collagen type I is a popular biomaterial for tissue engineering and regenerative medicine due to its abundance in the human body and its functions as a scaffold material, as well as its relatively low cost compared with other proteins [37,73,74]. Collagen consists 
of a triple helix (tropocollagen molecule), formed by three polypeptide chains that can self-assemble in different networks such as fibrils or fibers [72].

Collagen type I is important for osteoblast response and some studies showed that collagen type I coatings on Ti6Al4V alloy could enhance cell adhesion, osteoblast proliferation, and differentiation $[53,54]$. Collagen type I grafted on titanium substrates promoted early osseointegration in vivo [56]. A study from Hsueh et al. demonstrated that the adhesion and proliferation of E.coli were reduced as well as the cell adhesion of osteoblast cells improved by using collagen coatings containing silver nanoparticles [57]. Recently, a study from our group demonstrated the effect of collagen coatings enriched with phloroglucinol (PG) on fibroblast- and osteoblast-like cells [55]. Results showed that such coatings significantly reduce the gene expression of inflammatory markers. Moreover, the expression of an osteoclast activation marker was reduced at a low PG concentration and the expression of osteogenic differentiation marker was promoted at a high PG concentration.

\subsubsection{Amyloid Fibrillar Coatings}

Amyloids are $\beta$-sheet structures of protein and peptide aggregates that form fibrils at the nanoscale. These fibrils are obtained from diverse proteins or peptides, and especially from proteins coming from the food industry such as whey protein isolate (WPI) or lysozyme from hen egg white.

WPI comes from the whey, which is a by-product from the dairy industry that contains more than $95 \%$ of protein, of which $75 \%$ is $\beta$-lactoglobulin, whereas whey protein concentrate contains less protein than WPI (more than 80\%) [58]. WPI can form fibrils under acidic conditions $(<\mathrm{pH} 3.5)$ and a long heating time due to the degradation of $\beta$-lactoglobulin into peptides. These peptides self-assemble into fibrils of a few nanometers in thickness and a length between 1 to $10 \mu \mathrm{m}$ [75]. The morphology of these fibrils is $\mathrm{pH}$-dependent; it has been shown that it forms long semi-flexible fibers at $\mathrm{pH} 2$ and wormlike structures at $\mathrm{pH} 3.5$ [76-78]. Previous studies showed that WPI could improve cell proliferation and osteogenic differentiation. Moreover, it demonstrates some antibacterial properties $[58,59,79]$. Quantification of WPI fibrils in solution can be performed with the Thioflavin T fluorescence assay [80]. Furthermore, these WPI solutions may be enriched by different compounds such as antimicrobial molecules. Material surfaces could be covered by a thin film of WPI and previous works studied the antimicrobial properties of these coatings especially for food packaging [60,61]. Recent work demonstrated the ability of WPI fibril coatings to withstood autoclaving sterilization as well as support the spread and differentiation of human bone marrow stromal cells [39]. WPI has been extensively studied for food applications and it constitutes a new research area in the biomaterial field.

Amyloid fibrils can also be obtained from hen egg white lysozyme at high temperature and low $\mathrm{pH}$. Reynolds et al. produced fibrils from lysozyme at high temperature and low $\mathrm{pH}$. They demonstrated that this fibrillar coating could enhance cell spreading due to an increase in the number of focal adhesions compared with lysozyme control [48].

Recently, fibrils have been obtained from legume proteins instead of animal proteins such as whey or egg proteins. This could constitute another approach to coat material for cell support [81].

\subsubsection{Other Fibrillar Coatings}

Numerous other fibrous proteins may be used to modify material surfaces. One which has been widely studied is silk fibroin (SF) protein. Silk fibers are composed of two SF filaments which are formed by self-assembly of nanofibrils ( $3-5 \mathrm{~nm}$ in diameter) into larger fibrils (20-200 $\mathrm{nm}$ in diameter) [82]. SF possesses interesting biocompatibility but due to low antibacterial activity, it is often used in combination with other nanomaterials. For instance, SF coatings have been used as a matrix to incorporate gentamycin and silver nanoparticles in a previous study [62]. The antibacterial activity of these coatings has been successfully demonstrated by a significant reduction in bacterial growth and adhesion and biofilm formation. Furthermore, the attachment and proliferation of osteoblast-like 
cells were improved. In another study, polyetheretherketone (PEEK) has been coated with SF and bone-forming peptide to increase the osteogenesis of PEEK implant [63]. Results showed good cytocompatibility with an increase in cell proliferation, spreading, and osteogenic differentiation. SF nanofibers have also been obtained by electrospinning and modified with graphene oxide which resulted in a decrease in E. coli and S. aureus survival rates, as well as an increase in the growth of osteoblast-like cells [64]. Cestari et al. have also produced SF nanofibers by electrospinning [65]. In their work, heparin was successfully immobilized at the surface of SF nanofibers due to the formation of hydrogen bonds. Higher cell growth and proliferation were observed on the SF fibers with heparin [65].

\section{Synthetic Polymer Coatings}

Dopamine, a biomolecule with catechol and amine functionalities, can self-polymerize into polydopamine (PDA). Inspired by the adhesive foot proteins secreted by mussels, PDA has been used as a coating on various types of materials [83]. Due to the presence of chemical functionalities (catechol and amine groups), this coating can be further used as a platform to bind other compounds. For example, Cong et al. used this coating to bind and reduce silver ions to form a nanocomposite coating made of silver nanoparticles (Ag$\mathrm{NPs}$ ), which display interesting antibacterial properties [84]. Cotton fabrics have also been successfully modified with polydopamine to incorporate AgNPs to render them antibacterial [85]. Another work investigated the use of PDA to deposit AgNPs and polyethylene glycol (PEG) to create an antimicrobial and antifouling surface, respectively, due to the presence of AgNPs and PEG [86]. The combination of both properties, antibacterial and antifouling, was only possible through the PDA coating acting as a binding platform for AgNPs and PEG. Another way to produce antibacterial PDA coatings is by preparing the coating by a shaking-assisted method which leads to the formation of a roughened PDA coating [87], These coatings have exhibited strong antibacterial activity compared with smooth PDA coatings, which was close to $100 \%$ against E. coli, S. aureus, and P. aeruginosa. This antibacterial activity remained strong after 10 days of storage of the coatings in deionized water. Moreover, bacterial morphologies have been studied by scanning electron microscopy (SEM). The results showed major changes in their structure with a loss of the intact rod-like shape for E. coli and of the spherical shape for S. aureus, which may indicate damage of cell membrane.

Polyethyleneimine (PEI) is a cationic polymer containing the highest number of amine groups and it is mostly used as a precursor layer for polyelectrolyte multilayer films for dental and orthopedic implants or tissue engineering [88]. Previous studies showed that multilayer thin films of PEI/heparin on NiTi alloy demonstrate better biocompatibility compared with NiTi alloy itself $[88,89]$. In addition, PEI demonstrated some antibacterial properties against $S$. aureus and P. aeruginosa after $24 \mathrm{~h}$ and its non-cytotoxicity against fibroblasts after 7 days [90]. However, other studies have shown that PEI is cytotoxic; some authors say that this cytotoxicity is molecular weight-dependent, with lower molecular weight preparations demonstrating lower cytotoxicity [91,92]. The effect of PEI immobilization on poly (lactic acid) (PLLA) by adsorption or covalent binding has also been investigated using high and low molecular weight PEI. Results showed that cell adhesion was enhanced in the presence of PEI compared with uncoated PLLA. The proliferation and differentiation of an osteoblast cell line have been also improved, in particular by low molecular weight PEI [93]. Recently, another study evaluated adhesive properties and cytotoxicity towards human mesenchymal stromal cells (hMSCs) of PEI coatings [94]. PEI coatings improved cell adhesion after $1 \mathrm{~h}$ of incubation compared with uncoated culture plates. Cells also exhibited high metabolic activity in the presence of PEI with $10 \%$ fetal bovine serum. 


\section{Characterization of Amine-Rich Coatings}

\subsection{Physicochemical Characterization}

The wettability of a surface is a property related to the affinity of a liquid to this surface. Water contact angle (WCA) measurements are a simple and quick technique to determine wettability. By depositing a water droplet on the surface of the material, the WCA is measured with software. WCA is defined as the angle formed by water at the three-phase boundary where the water, air, and solid intersect [95]. WCA measurements can be used to detect the presence of a coating by comparison to the uncoated material. In fact, for amine-rich coatings, due to the introduction of hydrophilic nitrogen functionalities, the WCA decreases compared with the uncoated samples, as has been shown in previous studies [17]. Furthermore, surface wettability may influence cell behavior [96].

X-ray photoelectron spectroscopy (XPS), also known as electron spectroscopy for chemical analysis (ESCA), is a technique to analyze the surface chemistry of a material by measuring the elemental composition of the surface. With a survey spectrum, it is possible to detect the presence of nitrogen on the top surface of the material. Indeed, the $\mathrm{N}$ peak characteristic may be identified and estimated. With a high-resolution spectrum, the peak of the elements found in the survey can be separated into components corresponding to different chemical bonds $[97,98]$. However, the nitrogen high-resolution spectrum is difficult to analyze due to the close binding energy of each component (amine, imine, amide, ... ) and this might be not useful to perform [17].

Scanning electron microscopy (SEM) produces images of the surface with a focused electron beam scanning the surface. This reveals the surface topography of the sample. This method can be used to image the coatings, which may be important to show the possible defects, leading to a non-homogeneous layer. Moreover, fibrils from collagen [99] or WPI [39] are easily detected on the substrates (Figure 6). Finally, this method is also used to analyze the cell adhesion and spreading on the material [39] or the damage of bacteria after contact with the coating [87].

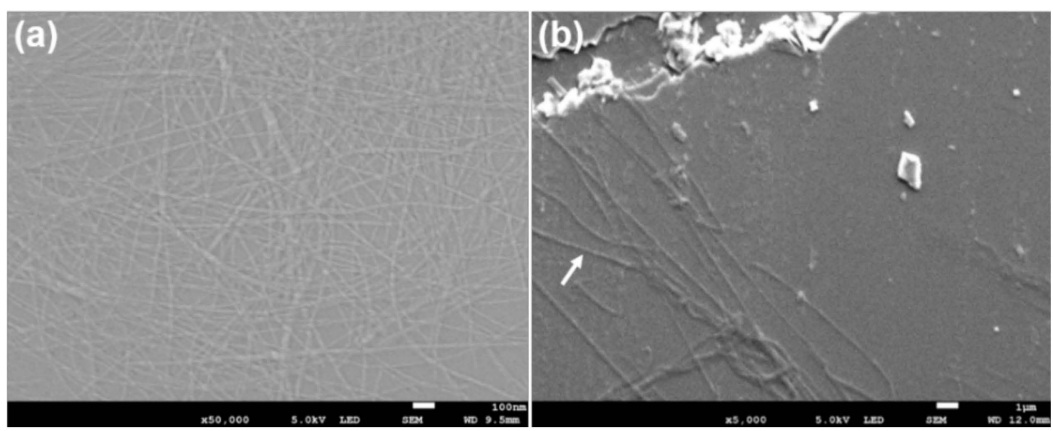

Figure 6. SEM images of (a) WPI fibrils and (b) collagen fibrils on glass substrates. Arrow indicates a collagen fibril. Scale bar: (a) $100 \mathrm{~nm}$ and (b) $1 \mu \mathrm{m}$.

Atomic force microscopy (AFM) is used to analyze the surface topography at an extremely low resolution $(<1 \mathrm{~nm})$, thanks to a sharpened probe scanning the surface. This method can be used to study the morphology of the coatings, as Michelmore et al. performed for allylamine plasma coatings by varying the treatment time. Fibrils from collagen or WPI can also be detected by this technique (Figure 7) $[40,48]$. Moreover, the surface roughness can be estimated, which is an important parameter since it affects cell behavior, especially cell morphology and cell proliferation [96], as well as bacterial growth [100]. 


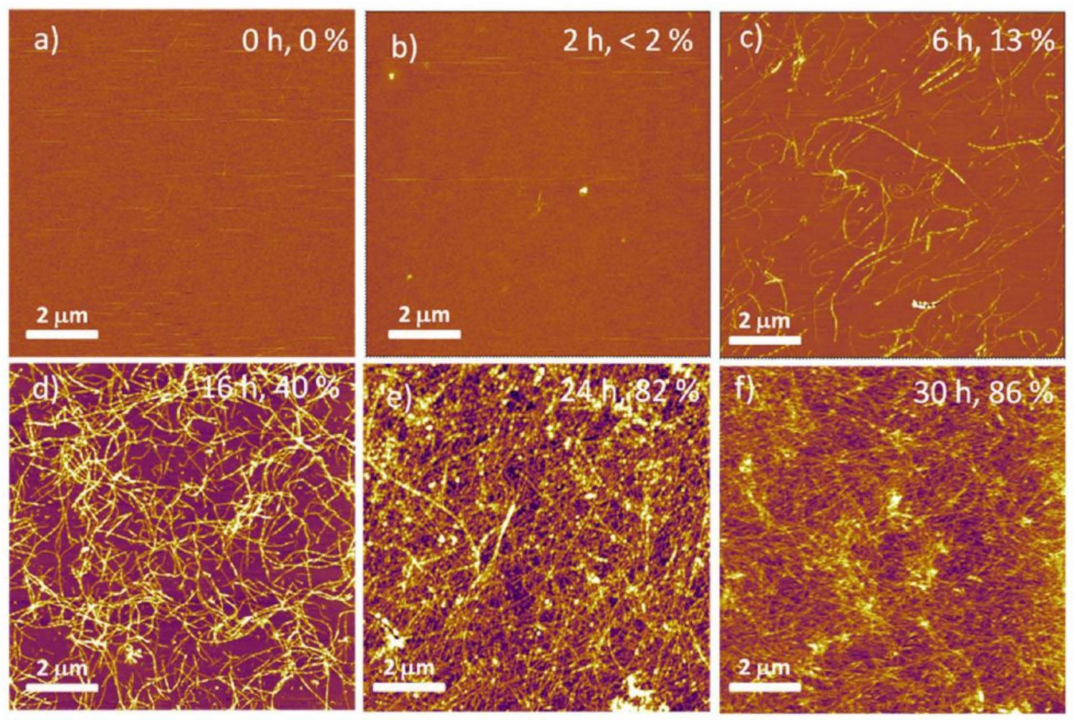

Figure 7. AFM images of (a) 2 wt.\% lysozyme solution, and (b-f) amyloid fibril network from lysozyme solution by incubating fibrillar suspensions onto mica substrates for $10 \mathrm{~min}$. Fibrillar suspensions formed at $90^{\circ} \mathrm{C}$ for (b) $2 \mathrm{~h},(\mathbf{c}) 6 \mathrm{~h},(\mathbf{d}) 16 \mathrm{~h},(\mathbf{e}) 24 \mathrm{~h}$, and (f) $30 \mathrm{~h} \mathrm{( \%} \mathrm{coverage} \mathrm{also} \mathrm{listed}$ on images). Z-scale $=10 \mathrm{~nm}$. Reprinted with permission from [48]. Copyright (2014) American Chemical Society.

Fourier-transform infrared spectroscopy (FTIR) is a method used to study the structural properties of materials, and especially the chemical bonds. This technique is based on the interaction between infrared light and vibrational states of the matter. Atoms in molecules are able to vibrate in different modes. When the frequency of a specific vibration mode is equal to the frequency of the incident infrared radiation, the molecule absorbs the radiation. The associated energy is converted into different types of motions. The vibrational motion is usually accompanied by other rotational motions. These combinations lead to the absorption bands commonly observed in the middle infrared region $\left(4000-400 \mathrm{~cm}^{-1}\right)$. This technique is useful to detect protein coatings with specific absorption bands (amide A, amide I, amide II, ... ) [62,101]. This technique has been used by Sima et al. to detect possible structural changes of the FN by identifying the characteristic peaks [51]. FTIR spectroscopy is also used to identify chemical bonds present in plasma polymer coatings and it usually shows the fragmentation and re-organization of the broken monomer used as well as the formation of new bonds as described by Abbas et al. [102].

\subsection{Amine Groups Quantification}

Different methods have been used to quantify the presence of amine groups:

- Dyes: A comparative study between Orange II and Coomassie Brilliant Blue dyes showed that Orange II dye seems to be the most appropriate in the case of primary amine grafted on polyethylene terephthalate (PET) [103]. In another study, the Orange II dye was used on PET membrane treated by allylamine plasma. A positive correlation was found between the results of the colorimetric staining and XPS and FTIR analyses. Coomassie Brilliant Blue is commonly used following the amino density estimation by colorimetric assay (ADECA) method based on the reversible formation of a complex of $\mathrm{CBB}$ with the $\mathrm{N}^{+}$groups [104]. After staining and washing, the dye in solution is quantified, leading to an evaluation of the amine groups. The reversibility of the process provides an advantage to this method. However, this method seems to be less reliable than the Orange II quantification method due to steric hindrance that limits the interaction between the dye and amine groups [103].

- Chemical derivatization: Chemical derivatization is widely used by grafting glutaraldehyde with an enzyme detectable by fluorescence spectroscopy or microscopy [30]. 
Regarding plasma deposition, in the vapor phase, amine groups may be identified via the grafting of compounds such as 4-trifluoromethyl-benzaldehyde (TFBA) as shown in Figure 8 [8] or pentafluorobenzaldehyde (PFBA) [97] in the vapor phase. For example, TFBA can be chemically grafted via imine bonds to $-\mathrm{NH}_{2}$ groups. Then, XPS analyses are performed to detect the presence of fluorine in the coating.
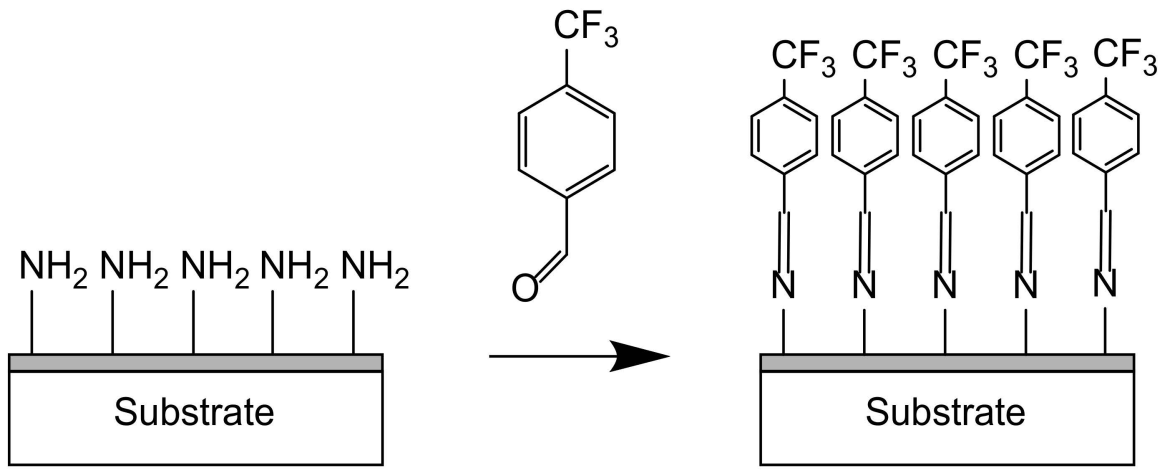

Figure 8. TFBA derivatization of primary amines. TFBA molecules are chemically grafted to the primary amines which are present in the coating. Then, fluorine can be quantified by XPS which allows the quantification of primary amines.

\section{Conclusions}

Multiple methods have been developed to create amine-rich coatings such as plasma techniques and more importantly plasma polymerization, which is a method widely used for its numerous advantages (quick deposition, homogeneous coating, deposition on multiple samples in a one-step process). However, this method requires an equipment which may be expensive due to the pumping system. Moreover, these amine coatings may be obtained from biomolecules such as proteins. The ability of proteins to form fibrils (collagen fibrils or amyloid fibrils) makes them interesting due to their high surface/volume ratio, which increases the fibril adhesion. They can be used as a matrix to incorporate other molecules with additional, desirable characteristics such as antimicrobial properties. Collagen fibril coatings have been deeply investigated but this method can also be expensive due to the high cost of collagen. However, much less work has been performed on amyloid fibrils and especially fibrils from whey protein (a by-product from the dairy industry), which is an inexpensive protein possessing interesting properties. Synthetic polymers such as polyethyleneimine or polydopamine have been used as coatings to control cell behavior, and they might have antibacterial properties. This effect needs to be investigated in more detail since the results have been controversial. Their possible cytotoxicity has to be more studied since it must be avoided for biomedical applications. To summarize, these strategies still need to be explored in order to obtain amine functional coatings for biomaterial applications such as implants, which could prevent bacterial infection as well as enhancing cell adhesion, proliferation, and differentiation.

Author Contributions: Conceptualization, L.M. and T.E.L.D.; formal analysis, L.M.; investigation, L.M.; writing —original draft preparation, L.M.; writing—review and editing, L.M. and T.E.L.D.; supervision, T.E.L.D.; project administration, T.E.L.D. All authors have read and agreed to the published version of the manuscript.

Funding: This research was funded by EPSRC "A novel coating technology based upon polyatomic ions from plasma" grant number EP/S004505/1 (L.M.).

Institutional Review Board Statement: Not applicable.

Informed Consent Statement: Not applicable. 
Data Availability Statement: Not applicable, all new data obtained by the authors is shown in the manuscript. All results of other scientists which have been referenced are available at the cited sources.

Acknowledgments: The authors would like to acknowledge Sara Baldock for her assistance with the acquisition of the SEM images.

Conflicts of Interest: The authors declare no conflict of interest. The funders had no role in the design of the study; in the collection, analyses, or interpretation of data; in the writing of the manuscript, or in the decision to publish the results.

\section{References}

1. Health Care-Associated Infections_Fact Sheet. Available online: https://www.who.int/gpsc/country_work/gpsc_ccisc_fact_ sheet_en.pdf (accessed on 14 February 2020).

2. O'Neill, J. Antimicrobial Resistance: Tackling a Crisis for the Health and Wealth of Nations. 2014. Available online: https:/ / www.jpiamr.eu/wp-content/uploads/2014/12/AMR-Review-Paper-Tackling-a-crisis-for-the-health-and-wealth-ofnations_1-2.pdf (accessed on 14 February 2020).

3. Monegro, A.F.; Regunath, H.; Hospital Acquired Infections. StatPearls. 2020. Available online: https://www.ncbi.nlm.nih.gov/ books /NBK441857/ (accessed on 14 February 2020).

4. Badia, J.M.; Casey, A.L.; Petrosillo, N.; Hudson, P.M.; Mitchell, S.A.; Crosby, C. Impact of surgical site infection on healthcare costs and patient outcomes: A systematic review in six European countries. J. Hosp. Infect. 2017, 96, 1-15. [CrossRef]

5. Wertheimer, M.R.; St-Georges-Robillard, A.; Lerouge, S.; Mwale, F.; Elkin, B.; Oehr, C.; Wirges, W.; Gerhard, R. Fabrication and characterization of organic thin films for applications in tissue engineering: Emphasis on cell-surface interactions. MRS Online Proc. Libr. 2012, 1469, 43-48. [CrossRef]

6. Liu, X.; Feng, Q.; Bachhuka, A.; Vasilev, K. Surface modification by allylamine plasma polymerization promotes osteogenic differentiation of human adipose-derived stem cells. ACS Appl. Mater. Interfaces 2014, 6, 9733-9741. [CrossRef]

7. Siow, K.S.; Britcher, L.; Kumar, S.; Griesser, H.J. Plasma methods for the generation of chemically reactive surfaces for biomolecule immobilization and cell colonization-A review. Plasma Process. Polym. 2006, 3, 392-418. [CrossRef]

8. Meyer-Plath, A.A.; Schröder, K.; Finke, B.; Ohl, A. Current trends in biomaterial surface functionalization-Nitrogen-containing plasma assisted processes with enhanced selectivity. Vacuum 2003, 71, 391-406. [CrossRef]

9. Bílek, F.; Křižová, T.; Lehocký, M. Preparation of active antibacterial LDPE surface through multistep physicochemical approach: I. Allylamine grafting, attachment of antibacterial agent and antibacterial activity assessment. Colloids Surf. B Biointerfaces 2011, 88, 440-447. [CrossRef]

10. Reis, R.; Dumée, L.F.; He, L.; She, F.; Orbell, J.D.; Winther-Jensen, B.; Duke, M.C. Amine enrichment of thin-film composite membranes via low pressure plasma polymerization for antimicrobial adhesion. ACS Appl. Mater. Interfaces 2015, 7, 14644-14653. [CrossRef]

11. Vasilev, K.; Sah, V.R.; Goreham, R.V.; Ndi, C.; Short, R.D.; Griesser, H.J. Antibacterial surfaces by adsorptive binding of polyvinylsulphonate- stabilized silver nanoparticles. Nanotechnology 2010, 21, 215102. [CrossRef]

12. Aziz, G.; De Geyter, N.; Morent, R. Incorporation of primary amines via plasma technology on biomaterials. In Advances in Bioengineering; InTech: London, UK, 2015.

13. Chu, P.K.; Chen, J.Y.; Wang, L.P.; Huang, N. Plasma-surface modification of biomaterials. Mater. Sci. Eng. R Rep. 2002, 36, 143-206. [CrossRef]

14. Lieberman, M.A.; Lichtenberg, A.J. Principles of Plasma Discharges and Materials Processing; John Wiley \& Sons, Inc.: Hoboken, NJ, USA, 2005; ISBN 9780471724254.

15. Song, H.; Jung, S.C.; Kim, B.H. Focal adhesion of osteoblastic cells on titanium surface with amine functionalities formed by plasma polymerization. Jpn. J. Appl. Phys. 2012, 51, 08HE01. [CrossRef]

16. Ren, T.B.; Weigel, T.; Groth, T.; Lendlein, A. Microwave plasma surface modification of silicone elastomer with allylamine for improvement of biocompatibility. J. Biomed. Mater. Res. Part A 2008, 86A, 209-219. [CrossRef]

17. Aziz, G.; De Geyter, N.; Declercq, H.; Cornelissen, R.; Morent, R. Incorporation of amine moieties onto ultra-high molecular weight polyethylene (UHMWPE) surface via plasma and UV polymerization of allylamine. Surf. Coat. Technol. 2015, $271,39-47$. [CrossRef]

18. Aziz, G.; Thukkaram, M.; De Geyter, N.; Morent, R. Plasma parameters effects on the properties, aging and stability behaviors of allylamine plasma coated ultra-high molecular weight polyethylene (UHMWPE) films. Appl. Surf. Sci. 2017, 409, 381-395. [CrossRef]

19. Vasilev, K.; Michelmore, A.; Martinek, P.; Chan, J.; Sah, V.; Griesser, H.J.; Short, R.D. Early stages of growth of plasma polymer coatings deposited from nitrogen- and oxygen-containing monomers. Plasma Process. Polym. 2010, 7, 824-835. [CrossRef]

20. Zhao, J.H.; Michalski, W.P.; Williams, C.; Li, L.; Xu, H.S.; Lamb, P.R.; Jones, S.; Zhou, Y.M.; Dai, X.J. Controlling cell growth on titanium by surface functionalization of heptylamine using a novel combined plasma polymerization mode. J. Biomed. Mater. Res. Part A 2011, 97A, 127-134. [CrossRef] 
21. Finke, B.; Hempel, F.; Testrich, H.; Artemenko, A.; Rebl, H.; Kylián, O.; Meichsner, J.; Biederman, H.; Nebe, B.; Weltmann, K.D.; et al. Plasma processes for cell-adhesive titanium surfaces based on nitrogen-containing coatings. Surf. Coat. Technol. $2011,205$. [CrossRef]

22. Testrich, H.; Rebl, H.; Finke, B.; Hempel, F.; Nebe, B.; Meichsner, J. Aging effects of plasma polymerized ethylenediamine (PPEDA) thin films on cell-adhesive implant coatings. Mater. Sci. Eng. C 2013, 33, 3875-3880. [CrossRef]

23. Gigout, A.; Ruiz, J.-C.; Wertheimer, M.R.; Jolicoeur, M.; Lerouge, S. Nitrogen-rich plasma-polymerized coatings on PET and PTFE surfaces improve endothelial cell attachment and resistance to shear flow. Macromol. Biosci. 2011, 11, 1110-1119. [CrossRef]

24. Truica-Marasescu, F.; Wertheimer, M.R. Nitrogen-rich plasma-polymer films for biomedical applications. Plasma Process. Polym. 2008, 5, 44-57. [CrossRef]

25. Ruiz, J.C.; St-Georges-Robillard, A.; Thérésy, C.; Lerouge, S.; Wertheimer, M.R. Fabrication and characterisation of amine-rich organic thin films: Focus on stability. Plasma Process. Polym. 2010, 7, 737-753. [CrossRef]

26. Babaei, S.; Girard-Lauriault, P.L. Tuning the surface properties of oxygen-rich and nitrogen-rich plasma polymers: Functional groups and surface charge. Plasma Chem. Plasma Process. 2016, 36, 651-666. [CrossRef]

27. Naderi, J.; Giles, C.; Saboohi, S.; Griesser, H.J.; Coad, B.R. Combatting fungal biofilm formation by diffusive release of fluconazole from heptylamine plasma polymer coating. Biointerphases 2020, 15, 061012. [CrossRef]

28. Nemcakova, I.; Blahova, L.; Rysanek, P.; Blanquer, A.; Bacakova, L.; Zajiččová, L. Behaviour of vascular smooth muscle cells on amine plasma-coated materials with various chemical structures and morphologies. Int. J. Mol. Sci. 2020, 21, 9467. [CrossRef]

29. Charbonneau, C.; Ruiz, J.-C.; Lequoy, P.; Hébert, M.-J.; De Crescenzo, G.; Wertheimer, M.R.; Lerouge, S. Chondroitin sulfate and epidermal growth factor immobilization after plasma polymerization: A versatile anti-apoptotic coating to promote healing around stent grafts. Macromol. Biosci. 2012, 12, 812-821. [CrossRef]

30. Abbas, A.; Vercaigne-Marko, D.; Supiot, P.; Bocquet, B.; Vivien, C.; Guillochon, D. Covalent attachment of trypsin on plasma polymerized allylamine. Colloids Surf. B Biointerfaces 2009, 73, 315-324. [CrossRef]

31. Gancarz, I.; Bryjak, J.; Poźniak, G.; Tylus, W. Plasma modified polymers as a support for enzyme immobilization II. Amines plasma. Eur. Polym. J. 2003, 39, 2217-2224. [CrossRef]

32. Yang, J.; Bei, J.; Wang, S. Enhanced cell affinity of poly (D,L-lactide) by combining plasma treatment with collagen anchorage. Biomaterials 2002, 23, 2607-2614. [CrossRef]

33. Simovic, S.; Losic, D.; Vasilev, K. Controlled drug release from porous materials by plasma polymer deposition. Chem. Commun. 2010, 46, 1317-1319. [CrossRef]

34. Girard-Lauriault, P.-L.; Truica-Marasescu, F.; Petit, A.; Wang, H.T.; Desjardins, P.; Antoniou, J.; Mwale, F.; Wertheimer, M.R. Adhesion of human U937 monocytes to nitrogen-rich organic thin films: Novel insights into the mechanism of cellular adhesion. Macromol. Biosci. 2009, 9, 911-921. [CrossRef]

35. Girard-Lauriault, P.-L.; Mwale, F.; Iordanova, M.; Demers, C.; Desjardins, P.; Wertheimer, M.R. Atmospheric pressure deposition of micropatterned nitrogen-rich plasma-polymer films for tissue engineering. Plasma Process. Polym. 2005, 2, 263-270. [CrossRef]

36. Bílek, F.; Sulovská, K.; Lehocký, M.; Sáha, P.; Humpolíček, P.; Mozetič, M.; Junkar, I. Preparation of active antibacterial LDPE surface through multistep physicochemical approach II: Graft type effect on antibacterial properties. Colloids Surf. B Biointerfaces 2013, 102, 842-848. [CrossRef]

37. Ghomi, E.R.; Nourbakhsh, N.; Kenari, M.A.; Zare, M.; Ramakrishna, S. Collagen-based biomaterials for biomedical applications. J. Biomed. Mater. Res. Part B Appl. Biomater. 2021. [CrossRef]

38. Hay, E. Cell Biology of Extracellular Matrix; Springer: New York, NY, USA, 1981; ISBN 978-1-4612-8226-6.

39. Rabe, R.; Hempel, U.; Martocq, L.; Keppler, J.K.; Aveyard, J.; Douglas, T.E.L. Dairy-inspired coatings for bone implants from whey protein isolate-derived self-assembled fibrils. Int. J. Mol. Sci. 2020, 21, 5544. [CrossRef]

40. Vandrovcova, M.; Douglas, T.E.L.; Heinemann, S.; Scharnweber, D.; Dubruel, P.; Bacakova, L. Collagen-lactoferrin fibrillar coatings enhance osteoblast proliferation and differentiation. J. Biomed. Mater. Res. Part A 2015, 103, 525-533. [CrossRef]

41. Douglas, T.; Heinemann, S.; Mietrach, C.; Hempel, U.; Bierbaum, S.; Scharnweber, D.; Worch, H. Interactions of collagen types I and II with chondroitin sulfates A-C and their effect on osteoblast adhesion. Biomacromolecules 2007, 8, 1085-1092. [CrossRef]

42. Haynes, C.A.; Norde, W. Globular proteins at solid/liquid interfaces. Colloids Surf. B Biointerfaces 1994, 2, 517-566. [CrossRef]

43. Norde, W. Adsorption of proteins from solution at the solid-liquid interface. Adv. Colloid Interface Sci. 1986, 25, 267-340. [CrossRef]

44. Hempel, U.; Preissler, C.; Vogel, S.; Möller, S.; Hintze, V.; Becher, J.; Schnabelrauch, M.; Rauner, M.; Hofbauer, L.C.; Dieter, P. Artificial extracellular matrices with oversulfated glycosaminoglycan derivatives promote the differentiation of osteoblastprecursor cells and premature osteoblasts. Biomed. Res. Int. 2014, 2014, 938368. [CrossRef]

45. Hempel, U.; Matthäus, C.; Preissler, C.; Möller, S.; Hintze, V.; Dieter, P. Artificial matrices with high-sulfated glycosaminoglycans and collagen are anti-inflammatory and pro-osteogenic for human mesenchymal stromal cells. J. Cell. Biochem. 2014, 115, 1561-1571. [CrossRef]

46. Knowles, T.P.J.; Oppenheim, T.W.; Buell, A.K.; Chirgadze, D.Y.; Welland, M.E. Nanostructured films from hierarchical selfassembly of amyloidogenic proteins. Nat. Nanotechnol. 2010, 5, 204-207. [CrossRef]

47. Reynolds, N.P.; Styan, K.E.; Easton, C.D.; Li, Y.; Waddington, L.; Lara, C.; Forsythe, J.S.; Mezzenga, R.; Hartley, P.G.; Muir, B.W. Nanotopographic surfaces with defined surface chemistries from amyloid fibril networks can control cell attachment. Biomacromolecules 2013, 14, 2305-2316. [CrossRef] 
48. Reynolds, N.P.; Charnley, M.; Mezzenga, R.; Hartley, P.G. Engineered lysozyme amyloid fibril networks support cellular growth and spreading. Biomacromolecules 2014, 15, 599-608. [CrossRef]

49. Reynolds, N.P.; Charnley, M.; Bongiovanni, M.N.; Hartley, P.G.; Gras, S.L. Biomimetic topography and chemistry control cell attachment to amyloid fibrils. Biomacromolecules 2015, 16, 1556-1565. [CrossRef]

50. Hindié, M.; Degat, M.C.; Gaudire, F.; Gallet, O.; Van Tassel, P.R.; Pauthe, E. Pre-osteoblasts on poly(l-lactic acid) and silicon oxide: Influence of fibronectin and albumin adsorption. Acta Biomater. 2011, 7, 387-394. [CrossRef]

51. Sima, F.; Davidson, P.; Pauthe, E.; Sima, L.E.; Gallet, O.; Mihailescu, I.N.; Anselme, K. Fibronectin layers by matrix-assisted pulsed laser evaporation from saline buffer-based cryogenic targets. Acta Biomater. 2011, 7, 3780-3788. [CrossRef]

52. Montaño-Machado, V.; Chevallier, P.; Mantovani, D.; Pauthe, E. On the potential for fibronectin/phosphorylcholine coatings on PTFE substrates to jointly modulate endothelial cell adhesion and hemocompatibility properties. Biomatter 2015, 5, e979679. [CrossRef]

53. Geißler, U.; Hempel, U.; Wolf, C.; Scharnweber, D.; Worch, H.; Wenzel, K.W. Collagen type I-coating of Ti6A14V promotes adhesion of osteoblasts. J. Biomed. Mater. Res. 2000, 51, 752-760. [CrossRef]

54. Roehlecke, C.; Witt, M.; Kasper, M.; Schulze, E.; Wolf, C.; Hofer, A.; Funk, R.H.W. Synergistic effect of titanium alloy and collagen type I on cell adhesion, proliferation and differentiation of osteoblast-like cells. Cells Tissues Organs 2001, 168, 178-187. [CrossRef]

55. Mieszkowska, A.; Beaumont, H.; Martocq, L.; Koptyug, A.; Surmeneva, M.A.; Surmenev, R.A.; Naderi, J.; Douglas, T.E.L.; Gurzawska-Comis, K.A. Phenolic-enriched collagen fibrillar coatings on titanium alloy to promote osteogenic differentiation and reduce inflammation. Int. J. Mol. Sci. 2020, 21, 6406. [CrossRef]

56. Morra, M.; Cassinelli, C.; Cascardo, G.; Cahalan, P.; Cahalan, L.; Fini, M.; Giardino, R. Surface engineering of titanium by collagen immobilization. Surface characterization and in vitro and in vivo studies. Biomaterials 2003, 24, 4639-4654. [CrossRef]

57. Hsueh, Y.H.; Cheng, C.Y.; Chien, H.W.; Huang, X.H.; Huang, C.W.; Wu, C.H.; Chen, S.T.; Ou, S.F. Synergistic effects of collagen and silver on the deposition characteristics, antibacterial ability, and cytocompatibility of a collagen/silver coating on titanium. $J$. Alloys Compd. 2020, 830, 154490. [CrossRef]

58. Douglas, T.E.L.; Vandrovcová, M.; Kročilová, N.; Keppler, J.K.; Zárubová, J.; Skirtach, A.G.; Bačáková, L. Application of whey protein isolate in bone regeneration: Effects on growth and osteogenic differentiation of bone-forming cells. J. Dairy Sci. 2018, 101, 28-36. [CrossRef]

59. Gupta, D.; Kocot, M.; Tryba, A.M.; Serafim, A.; Stancu, I.C.; Jaegermann, Z.; Pamuła, E.; Reilly, G.C.; Douglas, T.E.L. Novel naturally derived whey protein isolate and aragonite biocomposite hydrogels have potential for bone regeneration. Mater. Des. 2020, 188, 108408. [CrossRef]

60. Gadang, V.P.; Hettiarachchy, N.S.; Johnson, M.G.; Owens, C. Evaluation of antibacterial activity of whey protein isolate coating incorporated with nisin, grape seed extract, Malic Acid, and EDTA on a Turkey Frankfurter system. J. Food Sci. 2008, 73, M389-M394. [CrossRef]

61. Seydim, A.C.; Sarikus, G. Antimicrobial activity of whey protein based edible films incorporated with oregano, rosemary and garlic essential oils. Food Res. Int. 2006, 39, 639-644. [CrossRef]

62. Zhou, W.; Jia, Z.; Xiong, P.; Yan, J.; Li, Y.; Li, M.; Cheng, Y.; Zheng, Y. Bioinspired and biomimetic AgNPs/gentamicin-embedded silk fibroin coatings for robust antibacterial and osteogenetic applications. ACS Appl. Mater. Interfaces 2017, 9, 25830-25846. [CrossRef]

63. Wang, C.; Wang, S.; Yang, Y.; Jiang, Z.; Deng, Y.; Song, S.; Yang, W.; Chen, Z.G. Bioinspired, biocompatible and peptide-decorated silk fibroin coatings for enhanced osteogenesis of bioinert implant. J. Biomater. Sci. Polym. Ed. 2018, 29, 1595-1611. [CrossRef]

64. Wang, S.D.; Ma, Q.; Wang, K.; Chen, H.W. Improving antibacterial activity and biocompatibility of bioinspired electrospinning silk fibroin nanofibers modified by graphene oxide. ACS Omega 2017, 3, 406-413. [CrossRef]

65. Cestari, M.; Muller, V.; Rodrigues, J.H.D.S.; Nakamura, C.V.; Rubira, A.F.; Muniz, E.C. Preparing silk fibroin nanofibers through electrospinning: Further heparin immobilization toward hemocompatibility improvement. Biomacromolecules 2014, 15, $1762-1767$. [CrossRef]

66. Sottile, J.; Hocking, D.C. Fibronectin polymerization regulates the composition and stability of extracellular matrix fibrils and cell-matrix adhesions. Mol. Biol. Cell 2002, 13, 3546-3559. [CrossRef]

67. Ward, M.; Marcey, D. Fibronectin, an Extracellular Adhesion Molecule. Available online: http://biology.kenyon.edu/BMB/ Chime/Fibronectin/frames/fibrotxt.htm (accessed on 27 April 2018).

68. An, Y.H.; Friedman, R.J. Concise review of mechanisms of bacterial adhesion to biomaterial surfaces. J. Biomed. Mater. Res. 1998, 43, 338-348. [CrossRef]

69. Hay, E. Cell Biology of Extracellular Matrix, 2nd ed.; Springer Science \& Business Media: Berlin, Germany, 1991; ISBN 9780306439513.

70. Parisi, L.; Toffoli, A.; Ghezzi, B.; Mozzoni, B.; Lumetti, S.; Macaluso, G.M. A glance on the role of fibronectin in controlling cell response at biomaterial interface. Jpn. Dent. Sci. Rev. 2020, 56, 50-55. [CrossRef]

71. García, A.J.; Vega, M.D.; Boettiger, D. Modulation of cell proliferation and differentiation through substrate- dependent changes in fibronectin conformation. Mol. Biol. Cell 1999, 10, 785-798. [CrossRef] [PubMed]

72. Ricard-Blum, S. The collagen family. Cold Spring Harb. Perspect. Biol. 2011, 3, 1-19. [CrossRef]

73. Brett, D. A review of collagen and collagen-based wound dressings. Wounds 2008, 20, 347-356.

74. Khan, R.; Khan, M.H. Use of collagen as a biomaterial: An update. J. Indian Soc. Periodontol. 2013, 17, 539. [CrossRef] 
75. Akkermans, C.; Venema, P.; van der Goot, A.J.; Gruppen, H.; Bakx, E.J.; Boom, R.M.; van der Linden, E. Peptides are building blocks of heat-induced fibrillar protein aggregates of $\beta$-lactoglobulin formed at pH 2. Biomacromolecules 2008, 9, 1474-1479. [CrossRef]

76. Heyn, T.R.; Garamus, V.M.; Neumann, H.R.; Uttinger, M.J.; Guckeisen, T.; Heuer, M.; Selhuber-Unkel, C.; Peukert, W.; Keppler, J.K. Influence of the polydispersity of $\mathrm{pH} 2$ and $\mathrm{pH} 3.5$ beta-lactoglobulin amyloid fibril solutions on analytical methods. Eur. Polym. J. 2019, 120. [CrossRef]

77. Keppler, J.K.; Heyn, T.R.; Meissner, P.M.; Schrader, K.; Schwarz, K. Protein oxidation during temperature-induced amyloid aggregation of beta-lactoglobulin. Food Chem. 2019, 289, 223-231. [CrossRef]

78. Serfert, Y.; Lamprecht, C.; Tan, C.P.; Keppler, J.K.; Appel, E.; Rossier-Miranda, F.J.; Schroen, K.; Boom, R.M.; Gorb, S.; SelhuberUnkel, C.; et al. Characterisation and use of $\beta$-lactoglobulin fibrils for microencapsulation of lipophilic ingredients and oxidative stability thereof. J. Food Eng. 2014, 143, 53-61. [CrossRef]

79. Keppler, J.K.; Martin, D.; Garamus, V.M.; Berton-Carabin, C.; Nipoti, E.; Coenye, T.; Schwarz, K. Functionality of whey proteins covalently modified by allyl isothiocyanate: Part 1 physicochemical and antibacterial properties of native and modified whey proteins at pH 2 to 7. Food Hydrocoll. 2017, 65, 130-143. [CrossRef]

80. Loveday, S.M.; Wang, X.L.; Rao, M.A.; Anema, S.G.; Singh, H. $\beta$-Lactoglobulin nanofibrils: Effect of temperature on fibril formation kinetics, fibril morphology and the rheological properties of fibril dispersions. Food Hydrocoll. 2012, 27, 242-249. [CrossRef]

81. Li, T.; Wang, L.; Zhang, X.; Geng, H.; Xue, W.; Chen, Z. Assembly behavior, structural characterization and rheological properties of legume proteins based amyloid fibrils. Food Hydrocoll. 2021, 111, 106396. [CrossRef]

82. Nguyen, T.P.; Nguyen, Q.V.; Nguyen, V.H.; Le, T.H.; Huynh, V.Q.N.; Vo, D.V.N.; Trinh, Q.T.; Kim, S.Y.; Van Le, Q. Silk fibroin-based biomaterials for biomedical applications: A review. Polymers 2019, 11, 1933. [CrossRef] [PubMed]

83. Lee, H.; Dellatore, S.M.; Miller, W.M.; Messersmith, P.B. Mussel-inspired surface chemistry for multifunctional coatings. Science 2007, 318, 426-430. [CrossRef]

84. Cong, Y.; Xia, T.; Zou, M.; Li, Z.; Peng, B.; Guo, D.; Deng, Z. Mussel-inspired polydopamine coating as a versatile platform for synthesizing polystyrene/Ag nanocomposite particles with enhanced antibacterial activities. J. Mater. Chem. B 2014, 2, 3450-3461. [CrossRef]

85. Xu, H.; Shi, X.; Ma, H.; Lv, Y.; Zhang, L.; Mao, Z. The preparation and antibacterial effects of dopa-cotton/AgNPs. Appl. Surf. Sci. 2011, 257, 6799-6803. [CrossRef]

86. Sileika, T.S.; Kim, H.-D.; Maniak, P.; Messersmith, P.B. Antibacterial performance of polydopamine-modified polymer surfaces containing passive and active components. ACS Appl. Mater. Interfaces 2011, 3, 4602-4610. [CrossRef]

87. Su, L.; Yu, Y.; Zhao, Y.; Liang, F.; Zhang, X. Strong antibacterial polydopamine coatings prepared by a shaking-assisted method. Sci. Rep. 2016, 6. [CrossRef]

88. Dong, P.; Hao, W.; Xia, Y.; Da, G.; Wang, T. Comparison study of corrosion behavior and biocompatibility of polyethyleneimine (PEI)/heparin and chitosan/heparin coatings on NiTi alloy. J. Mater. Sci. Technol. 2010, 26, 1027-1031. [CrossRef]

89. Dong, P.; Hao, W.; Wang, X.; Wang, T. Fabrication and biocompatibility of polyethyleneimine/heparin self-assembly coating on NiTi alloy. Thin Solid Films 2008, 516, 5168-5171. [CrossRef]

90. Hernandez-Montelongo, J.; Lucchesi, E.G.; Nascimento, V.F.; França, C.G.; Gonzalez, I.; Macedo, W.A.A.; Machado, D.; Lancellotti, M.; Moraes, A.M.; Beppu, M.M.; et al. Antibacterial and non-cytotoxic ultra-thin polyethylenimine film. Mater. Sci. Eng. C 2017, 71, 718-724. [CrossRef] [PubMed]

91. Forrest, M.L.; Koerber, J.T.; Pack, D.W. A degradable polyethylenimine derivative with low toxicity for highly efficient gene delivery. Bioconjug. Chem. 2003, 14, 934-940. [CrossRef]

92. Brunot, C.; Ponsonnet, L.; Lagneau, C.; Farge, P.; Picart, C.; Grosgogeat, B. Cytotoxicity of polyethyleneimine (PEI), precursor base layer of polyelectrolyte multilayer films. Biomaterials 2007, 28, 632-640. [CrossRef]

93. Liu, Z.M.; Lee, S.Y.; Sarun, S.; Peschel, D.; Groth, T. Immobilization of poly (ethylene imine) on poly (1-lactide) promotes MG63 cell proliferation and function. J. Mater. Sci. Mater. Med. 2009, 20, 2317-2326. [CrossRef] [PubMed]

94. Liudmila, M.M.; Dmitriy, A.R.; Maria, G.F.; Evgeniy, E.F. Ultrathin polyethyleneimine (PEI) films for culturing of the human mesenchymal stromal cells (hMSCs). J. Cardiovasc. Med. Cardiol. 2020, 255-261. [CrossRef]

95. Kwok, D.Y.; Neumann, A.W. Contact angle measurement and contact angle interpretation. Adv. Colloid Interface Sci. 1999, 81, 167-249. [CrossRef]

96. Ferrari, M.; Cirisano, F.; Morán, M.C. Mammalian cell behavior on hydrophobic substrates: Influence of surface properties. Colloids Interf. 2019, 3, 48. [CrossRef]

97. Kim, J.; Jung, D.; Park, Y.; Kim, Y.; Moon, D.W.; Lee, T.G. Quantitative analysis of surface amine groups on plasma-polymerized ethylenediamine films using UV-visible spectroscopy compared to chemical derivatization with FT-IR spectroscopy, XPS and TOF-SIMS. Appl. Surf. Sci. 2007, 253, 4112-4118. [CrossRef]

98. Graf, N.; Yegen, E.; Gross, T.; Lippitz, A.; Weigel, W.; Krakert, S.; Terfort, A.; Unger, W.E.S. XPS and NEXAFS studies of aliphatic and aromatic amine species on functionalized surfaces. Surf. Sci. 2009, 603, 2849-2860. [CrossRef]

99. Norris, K.; Mishukova, O.I.; Zykwinska, A.; Colliec-Jouault, S.; Sinquin, C.; Koptioug, A.; Cuenot, S.; Kerns, J.G.; Surmeneva, M.A.; Surmenev, R.A.; et al. Marine polysaccharide-collagen coatings on Ti6Al4V alloy formed by self-assembly. Micromachines 2019, 10, 68. [CrossRef] 
100. Wu, S.; Zhang, B.; Liu, Y.; Suo, X.; Li, H. Influence of surface topography on bacterial adhesion: A review (Review). Biointerphases 2018, 13, 060801. [CrossRef]

101. Barth, A. Infrared spectroscopy of proteins. Biochim. Biophys. Acta Bioenerg. 2007, 1767, 1073-1101. [CrossRef]

102. Abbas, A.; Vivien, C.; Bocquet, B.; Guillochon, D.; Supiot, P. Preparation and multi-characterization of plasma polymerized allylamine films. Plasma Process. Polym. 2009, 6, 593-604. [CrossRef]

103. Noel, S.; Liberelle, B.; Robitaille, L.; De Crescenzo, G. Quantification of primary amine groups available for subsequent biofunctionalization of polymer surfaces. Bioconjug. Chem. 2011, 22, 1690-1699. [CrossRef] [PubMed]

104. Coussot, G.; Perrin, C.; Moreau, T.; Dobrijevic, M.; Le Postollec, A.; Vandenabeele-Trambouze, O. A rapid and reversible colorimetric assay for the characterization of aminated solid surfaces. Anal. Bioanal. Chem. 2011, 399, 1061-1069. [CrossRef] 